УДК 615.453.6:[615.31'495.9+615.31'792]

DOI https://doi.org/10.11603/2312-0967.2019.2.9927

\title{
ВИБІР ЗАХИСНОЇ ПОЛІМЕРНОЇ ОБОЛОНКИ ДЛЯ ТАБЛЕТОК-ЯДЕР L-АРГІНІНУ 3 ТІОТРИАЗОЛІНОМ
}

\section{О. В. Хромильова}

\author{
Запорізький державний медичний університет \\ НВО «Фарматрон», Запоріжжя \\ hromylova.olga@gmail.com
}

\section{ІНФОРМАЦІЯ}

Надійшла до редакції / Received: 12.05.2019

Після доопрацювання / Revised:

15.05.2019

Прийнято до друку / Accepted:

20.05.2019

\section{Ключові слова:}

L-аргінін;

інсульт;

таблетки;

тіотриазолін;

плівкова оболонка.

\begin{abstract}
АНОТАЦІЯ
Мета роботи. Вибір плівкоутворюючої системи для покриття таблеток-ядер L-аргініну з тіотриазоліном захисною полімерною оболонкою.

Матеріали і методи. Для отримання таблеток-ядер використовували субстанції тіотриазоліну, L-аргініну та зареєстровані допоміжні речовини. Таблетки-ядра отримували методом вологої грануляції в лабораторних умовах на кафедрі фрармацевтичної хімії Запорізького державного медичного університету. При нанесенні оболонки використовували плівкоутворюючі композиції торгової марки Опадрай в різноманітних концентраціях, установку для нанесення плівкоутворюючого покриття Glatt, об'єм барабана - 0,8 л, маса завантаження - 400 г. На таблетки-ядра наносили 3 \% плівкоутворювача. Результати й обговорення. У зв'язку з тим, що досліджувані плівкоутворюючі покриття при однаковій концентрації забезпечують різну в'язкість, для експерименту використовували рекомендоване виробником Colorcon співвідношення: для покриття з ГПМЦ готували 15 \% суспензію, а для покриття на основі ПВС 20 і 30 \% суспензію. На таблетки-ядра наносили 3 \% плівкоутворювача. Кожну серію отриманих таблеток оцінювали за зовнішнім виглядом, однорідністю маси, стійкістю таблеток до роздавлювання, часом розпадання. Дисперсійний аналіз експериментальних даних дослідження покритих таблеток L-аргініну з тіотриазоліном показав, що серед п'яти видів плівкоутворюючих систем найкращою є OPADRY.

Висновок. Проведено дослідження з вибору плівкоутворюючої суспензії для покриття таблеток-ядер L-аргініну з тіотриазоліном захисною полімерною оболонкою. За сукупністю отриманих показників - зовнішнього вигляду плівки, однорідності маси покритих таблеток, стійкістю до роздавлювання і часом розпадання раціонально використовувати $15 \%$ плівкоутворюючу суспензію OPADRY.
\end{abstract}

Вступ. На сьогодні інсульт забирає найбільше життів після онкологічних захворювань і є основною причиною тривалої непрацездатності населення в усьому світі. В Україні щорічно реєструється близько 111 тисяч випадків інсульту і майже кожен третій хворийпомирає. Томустворення новихкомбінованих лікарських засобів вітчизняного виробництва для лікування та проорілактики інсульту є актуальним завданнями сучасної фрармації [1]. При проведенні досліджень доведено доцільність створення нового комбінованого лікарського засобу на основі L-аргініну з тіотриазоліном [2, 3, 4, 5]. Розроблено

ISSN 2312-0967. Pharmaceutical review. 2019. № 2 
Фармацевтична технологія, біофармація, гомеопатія Pharmaceutical technology, biopharmacy, homeopathy

технологію таблеток L-аргініну 3 тіотриазоліном методом вологої грануляції [6, 7]. У процесі зберігання таблеток впродовж 2-х років кількісний вміст діючих речовин фрактично не змінився, однак якість поверхні таблеток не відповідала вимогам щодо зовнішнього вигляду. Оскільки отримані таблетки-ядра L-аргініну з тіотриазоліном належать до аміновмісних лікарських засобів, які мають низький термін зберігання, необхідне використання захисного покриття [8].

Мета роботи - вибір плівкоутворюючої системи для покриття таблеток-ядер L-аргініну з тіотриазоліном захисною полімерною оболонкою.

Матеріали і методи. Для отримання таблетокядер використовували субстанції тіотриазоліну (виробник: Державне підприємство «Завод хімічних реактивів» Науково-технологічного комплексу «Інститут монокристалів» HAH України), L-аргініну (виробник: «Sigma-Aldrich», США) та зареєстровані допоміжні речовини. Таблетки-ядра отримували методом вологої грануляції в лабораторних умовах на кафедрі фармацевтичної хімії Запорізького державного медичного університету. Для покриття використовували двояковипуклі таблетки-ядра L-арігніну 3 тіотриазоліном середньою масою 0,4002 г, діаметром 10 мм, стійкістю до роздавлювання 98,4 Н, стираністю 0,03\%, часом розпадання 5,29 хв. При нанесенні оболонки використовували плівкоутворюючі композиції торгової марки Опадрай в різноманітних концентраціях, установку для нанесення плівкоутворюючого покриття Glatt, об'єм барабана 0,8 л, маса завантаження 400 г. На таблетки-ядра наносили 3 \% плівкоутворювача.

Оскільки досліджувані плівкоутворюючі покриття при однаковій концентрації забезпечують різну в'язкість, для експерименту використовували рекомендоване виробником Colorcon співвідношення: для OPADRY i 03F22 готували $15 \%$ суспензію, а для покриття на основі OPADRY II ПВС і 85F22 20 \% суспензію і для покриття на основі OPADRY QX - 30 \% суспензію.

Таблетки-ядра L-арігніну з тіотриазоліном завантажували в барабан, який обертався із швидкістю
6 об./хв, швидкість вхідного повітря - 34 м³/год, температура нагрітих таблеток-ядер - $35^{\circ} \mathrm{C}$, час нагрівання та знепилення таблеток-ядер - 5 хв.

Збільшували швидкість обертів барабана до 8 об./хв і подавали через розпилюючу форсунку плівкоутворюючу суспензію на таблетки-ядра L-арігніну 3 тіотриазоліном. Температура повітря в барабані була 39-41 ${ }^{\circ} \mathrm{C}$. Час досушки покритих таблеток складав 5 хв при температурі $35^{\circ} \mathrm{C}$.

Результати й обговорення. Як плівкоутворюючі композиції використовували готові суміші торгової марки Опадрай, які найчастіше використовують вітчизняні фрармацевтичні підприємства в якості захисного покриття таблеток.

Перелік плівкоутворюючих систем, які використовували для покриття таблеток L-арігніну з тіотриазоліном, наведено в таблиці 1.

Кожну серію отриманих таблеток оцінювали за зовнішнім виглядом, однорідністю маси, стійкістю таблеток до роздавлювання, часом розпадання [8]. Peзультати дослідження представлено в таблиці 2.

Результати експериментальних досліджень підлягали дисперсійному аналізу за схемою, яка описана в монографрії [9].

Зовнішній вигляд покритих таблеток L-арігніну 3 тіотриазоліном експерти оцінювали за однорідністю кольору утвореної плівки, блискучістю поверхні, станом кромки покритих таблеток. Дисперсійний аналіз експериментальних даних з визначення зовнішнього вигляду покритих таблеток L-аргініну 3 тіотриазоліном показав незначущість досліджуваного показника $\mathrm{F}_{\text {експ }}=0,83<\mathrm{F}_{0,05}=3,83$.

Це означає, що при використанні будь-якої із 5-ти вивчених плівкоутворюючих систем отримуємо близькі за значенням результати щодо якості утвореної плівки. Найвищу оцінку експертів отримали покриті таблетки L-аргініну з тіотриазоліном при використанні плівкоутворюючої системи OPADRY.

Для покритих таблеток важливе значення має однорідність нанесення плівкоутворюючої суспензії. Відомо, що процес плівкоутворення залежить від складу плівкоутворюючої суспензії та режимів роботи дражувального котла. Показником, який характери-

\section{Таблиця 1}

Плівкоутворюючі системи та їх склад, які використовували для покриття таблеток L-аргініну з тіотриазоліном захисною оболонкою

\begin{tabular}{|l|l|}
\hline $\begin{array}{c}\text { Назва плівко- } \\
\text { утроюючої системи }\end{array}$ & \multicolumn{1}{c|}{ Склад плівкоутворюючої системи } \\
\hline $85 F 22$ & $\begin{array}{l}\text { Полівініловий спирт, макрогол, тальк, титану диоксид, заліза оксид жовтий, заліза оксид } \\
\text { червоний }\end{array}$ \\
\hline OPADRY QX & Полівініловий спирт, тальк, титану диоксид, моно/дигліцериди, заліза оксид жовтий \\
\hline 03F22 & $\begin{array}{l}\text { ГПМЦ 2910, титану диоксид, заліза оксид жовтий, макрогол, тальк, заліза оксид } \\
\text { червоний }\end{array}$ \\
\hline OPADRY & ГПМЦ 2910, титану диоксид, тальк, макрогол, заліза оксид жовтий \\
\hline OPADRY II & Полівініловий спирт, титану диоксид, макрогол, тальк, заліза оксид жовтий \\
\hline
\end{tabular}

ISSN 2312-0967. Фармацевтичний часопис. 2019. № 2 
Фармацевтична технологія, біофармація, гомеопатія Pharmaceutical technology, biopharmacy, homeopathy

Таблиця 2

Результати дослідження таблеток L-аргініну з тіотриазоліном, покритих плівковою оболонкою

\begin{tabular}{|l|c|c|c|c|c|c|c|c|c|c|c|c|}
\hline Тип оболонки & $\mathrm{y}_{1}$ & $\mathrm{y}_{1}^{\prime}$ & $\mathrm{y}_{2}$ & $\mathrm{y}_{2}^{\prime}$ & $\mathrm{y}_{3}$ & $\mathrm{y}_{3}^{\prime}$ & $\mathrm{y}_{4}$ & $\mathrm{y}_{4}^{\prime}$ & $\mathrm{y}_{5}$ & $\mathrm{y}_{5}^{\prime}$ & D & $\mathbf{D}^{\prime}$ \\
\hline 85F22 & 4 & 4 & 0,65 & 0,79 & 269,05 & 256,24 & 13,46 & 12,58 & 97,56 & 98,42 & 0,54 & 0,79 \\
\hline OPADRY QX & 4 & 5 & 0,74 & 0,63 & 264,3 & 272,42 & 7,5 & 7,24 & 99,78 & 99,34 & 0,92 & 0,95 \\
\hline 03F22 & 4 & 5 & 0,51 & 0,65 & 247,2 & 223,36 & 8,27 & 8,04 & 98,69 & 99,02 & 0,88 & 0,87 \\
\hline OPADRY & 5 & 5 & 0,77 & 0,81 & 287,15 & 268,25 & 6,52 & 7,12 & 99,87 & 100,02 & 0,95 & 0,95 \\
\hline OPADRY II & 5 & 4 & 1,17 & 1,24 & 249,6 & 237,53 & 11,47 & 12,87 & 99,38 & 98,56 & 0,84 & 0,75 \\
\hline
\end{tabular}

Примітка: $y_{1}, y_{1}^{\prime}$ - зовнішній вид таблеток першої і другої серії дослідів відповідно, бали; $y_{2}, y_{2}^{\prime}-$ однорідність маси покритих таблеток першої і другої серії дослідів відповідно, $\pm \% ; y_{3}, y_{3}^{\prime}$-стійкість таблеток до роздавлювання першої і другої серії дослідів відповідно, $\mathrm{H} ; \mathrm{y}_{4}, \mathrm{y}_{4}^{\prime}-$ час розпадання таблеток першої і другої серії дослідів відповідно, хв, у y' $_{5}^{\prime}$ - вміст L-аргініну після 6 місяців зберігання першої і другої серії дослідів відповідно; D i D' - фрункція бажаності першої і другої серії дослідів відповідно.

зує рівномірність нанесення плівки на таблетки-ядра, є однорідність маси покритих таблеток. Ми для покриття відібрали таблетки-ядра з однорідністю дозування не більше $\pm 0,55 \%$. Після нанесення плівки на таблетки визначали однорідність маси покритих таблеток. Дисперсійний аналіз експериментальних даних показав, що на однорідність маси покритих таблеток впливає природа плівкоутворюючої системи $\mathrm{F}_{\text {експ. }}=20,05>\mathrm{F}_{0,05}=3,63$.

Вплив природи плівкоутворюючої суспензії на однорідність маси покритих таблеток L-арігніну з тіотриазоліном зображено на рисунку 1.

Дані рисунка 1 підтверджують, що найменше відхилення в масі покритих таблеток L-аргініну з тіотриазоліном спостерігається при використанні як плівкоутворюючої суспензії 35F22 ( $\pm 0,58 \%)$, наступні місця щодо однорідності маси покритих таблеток займають OPADRY QX $( \pm 0,68 \%), 85 F 22( \pm 0,72 \%)$, OPADRY $( \pm 0,79 \%)$ i OPADRY II $( \pm 1,20 \%)$.
Процес покриття таблеток також характеризується стійкістю до роздавлювання - чим більше значення цього показника, тим рівномірнішою є адгезія покриття до поверхні таблеток та більш міцнішою $є$ плівка. Дисперсійний аналіз даних показав статистичну значущість стійкості покритих таблеток від природи використаних плівкоутворючих суспензій $\mathrm{F}_{\text {екс. }}=4,76>\mathrm{F}_{0,05}=3,63$. Вплив природи плівкоутворюючої суспензії на стійкість покритих таблеток таблеток L-аргініну з тіотриазоліном до роздавлювання показано на рисунку 2.

За даними рисунка 2, найбільш стійкими до роздавлювання покриті таблетки отримали при використанні як плівкоутворювача OPADRY $(272,7$ H), якому дещо поступається OPADRY QX $(268,36$ H) i суттєво поступаються 85F22 (259,64 H), OPADRY II $(243,55$ H) і 03F22 (240,26 H). Зазначимо, що стійкість непокритих таблеток-ядер не перевищувала 99 Н. Плівкова оболонка збільшує стійкість покри-

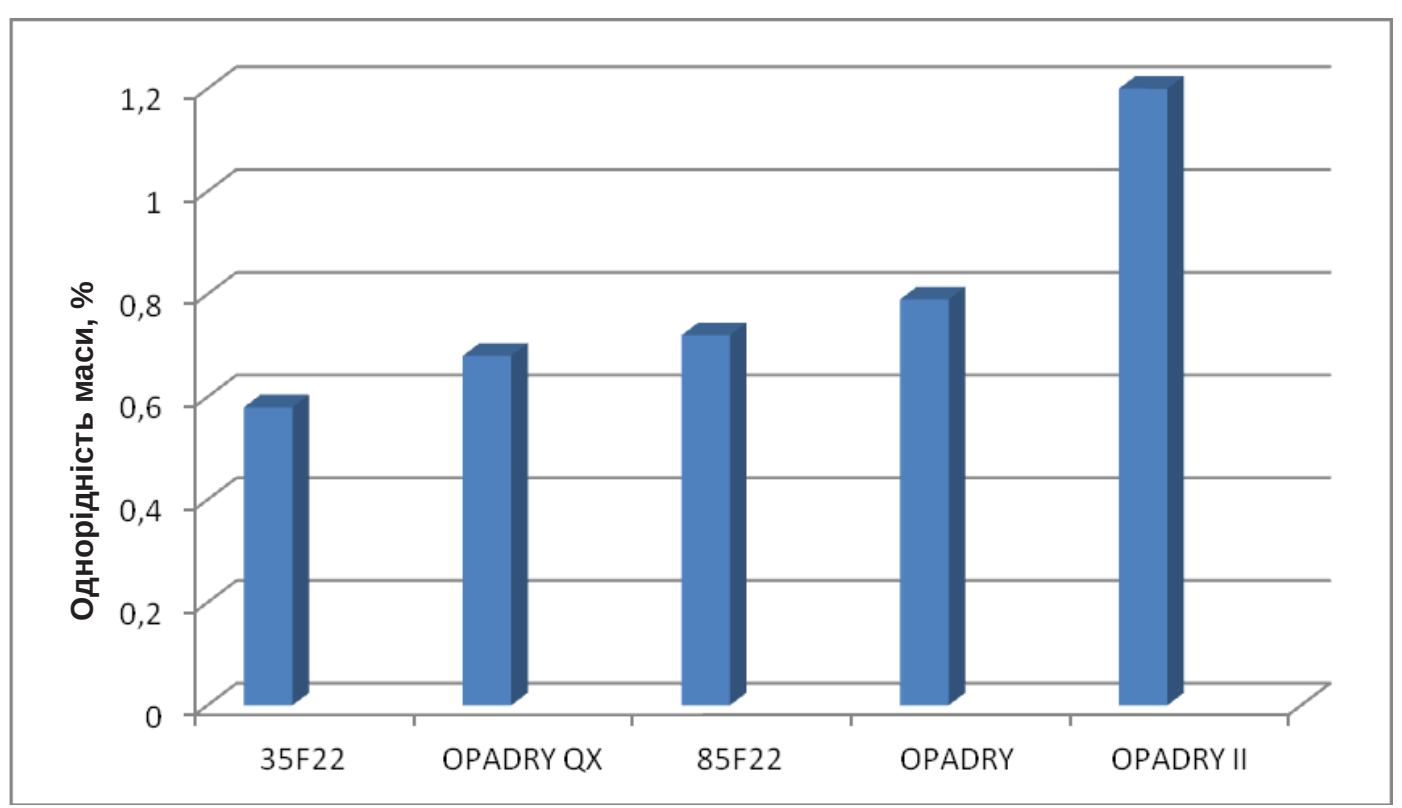

Рис. 1. Вплив різних видів плівкоутворюючого покриття на однорідність маси таблеток L-аргініну з тіотриазоліном.

ISSN 2312-0967. Pharmaceutical review. 2019. № 2 
Фармацевтична технологія, біофармація, гомеопатія Pharmaceutical technology, biopharmacy, homeopathy

тих таблеток в 2,23-2,77 раза порівняно з непокритими.

Дисперсійний аналіз показав, що природа плівкоутворюючої суспензії суттєво впливає на час розпадання покритих таблеток $\mathrm{F}_{\text {експ }}=51,42>\mathrm{F}_{0,05}=3,63$. Вплив природи плівкоутворюючої суспензії на час розпадання покритих таблеток зображено на рисунку 3.

За впливом на розпадання таблеток L-аргініну 3 тіотриазоліном плівкові покриття розміщуються в такій послідовності: OPADRY $(6,8$ хв) > OPADRY QX $(7,4$ хв) > 03F22 (8,1 хв.) > OPADRY II $(12,2$ хв) > 85F22 (13,0 хв). Час розпадання непокритих таблеток-ядер не перевищував 5,3 хв. Нанесена на таблетки полімерна плівка дещо сповільнює їхнє розпадання, однак у всіх серіях дослідів воно витримує вимоги ДФ України до покритих оболонкою таблеток.

Покриті полімерною оболонкою таблетки L-аргініну 3 тіотриазоліном зберігали в упаковці протягом 6-ти місяців. Після цього проводили кількісне визначення діючих речовин в покритих таблетках. Результати кількісного визначення тіотриазоліну в покритих таблетках показали, що вміст діючої речовини практично не змінюється, тому первинних даних ми не наводимо.

Кількісний вміст L-аргініну в покритих таблетках змінюється в процесі їх зберігання. Дисперсійний аналіз даних показав статистичну значущість кількісного вмісту L-аргініну покритих таблеток від природи використаних плівкоутворюючих суспензій $\mathrm{F}_{\text {експ }}=$ $6,23>\mathrm{F}_{0,05}=3,63$.

Вплив природи плівкоутворюючої суспензії на кількісний вміст L-аргініну в покритих таблетках 30бражено на рисунку 4.

За даними рисунка 4, за впливом на кількісний вміст L-аргініну плівкові покриття розміщуються в такій послідовності: OPADRY $(99,94 \%)>$ OPADRY QX $(99,56 \%)>$ OPADRY II $(98,97 \%)>03 F 22(98,85 \%)>$ 85F22 (97,99 \%).

Для вибору кращої плівкоутворюючої системи використовували узагальнений показник - фуункцію бажаності. Для цього первинні результати за показника-

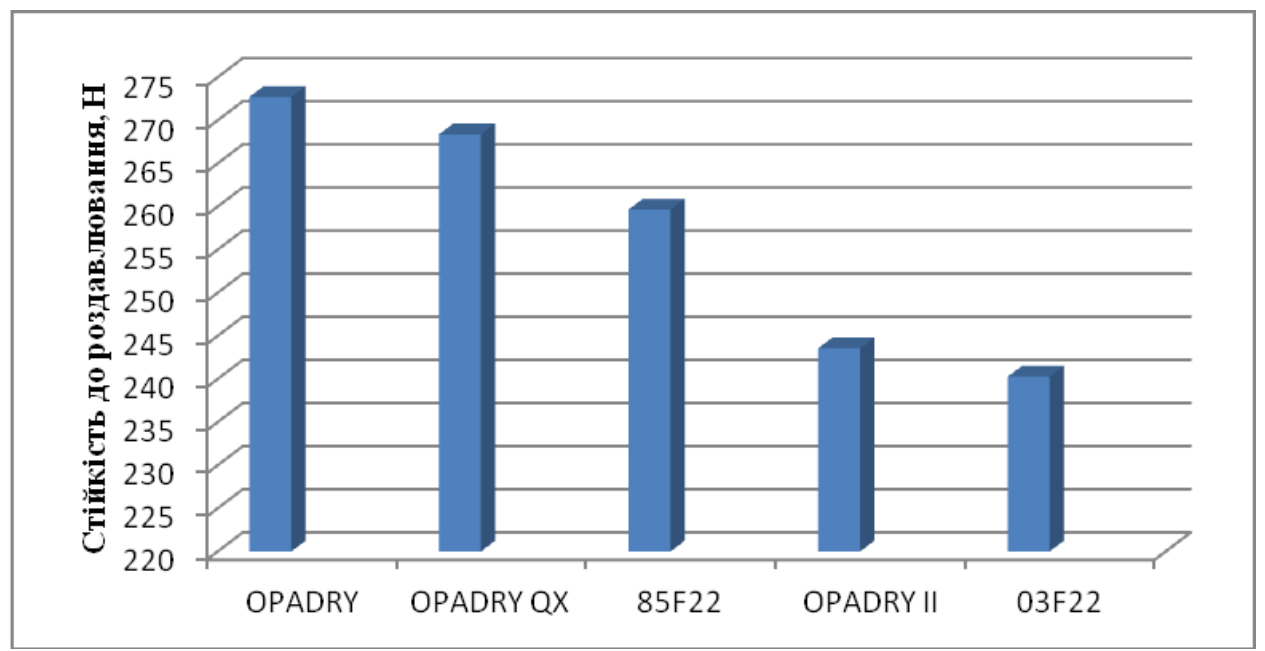

Рис. 2. Вплив різних видів плівкоутворюючого покриття на стійкість таблеток L-аргініну з тіотриазоліном до роздавлювання.

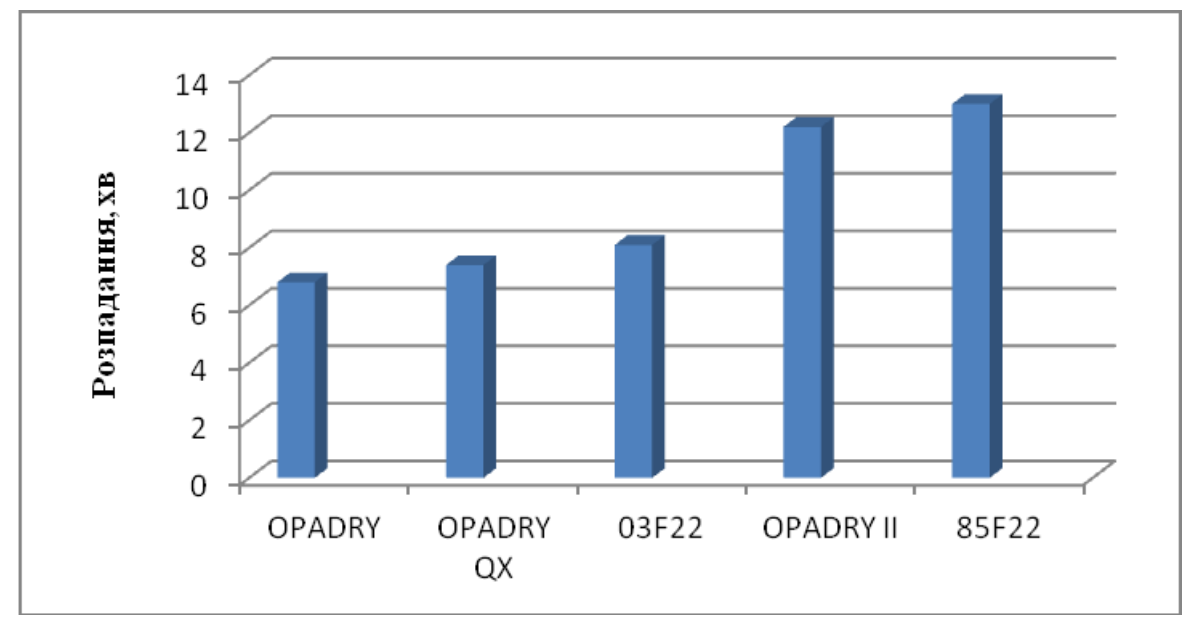

Рис. 3. Вплив природи плівкоутворюючого покриття на розпадання таблеток L-аргініну з тіотриазоліном.

ISSN 2312-0967. Фармацевтичний часопис. 2019. № 2 
Фармацевтична технологія, біофармація, гомеопатія Pharmaceutical technology, biopharmacy, homeopathy

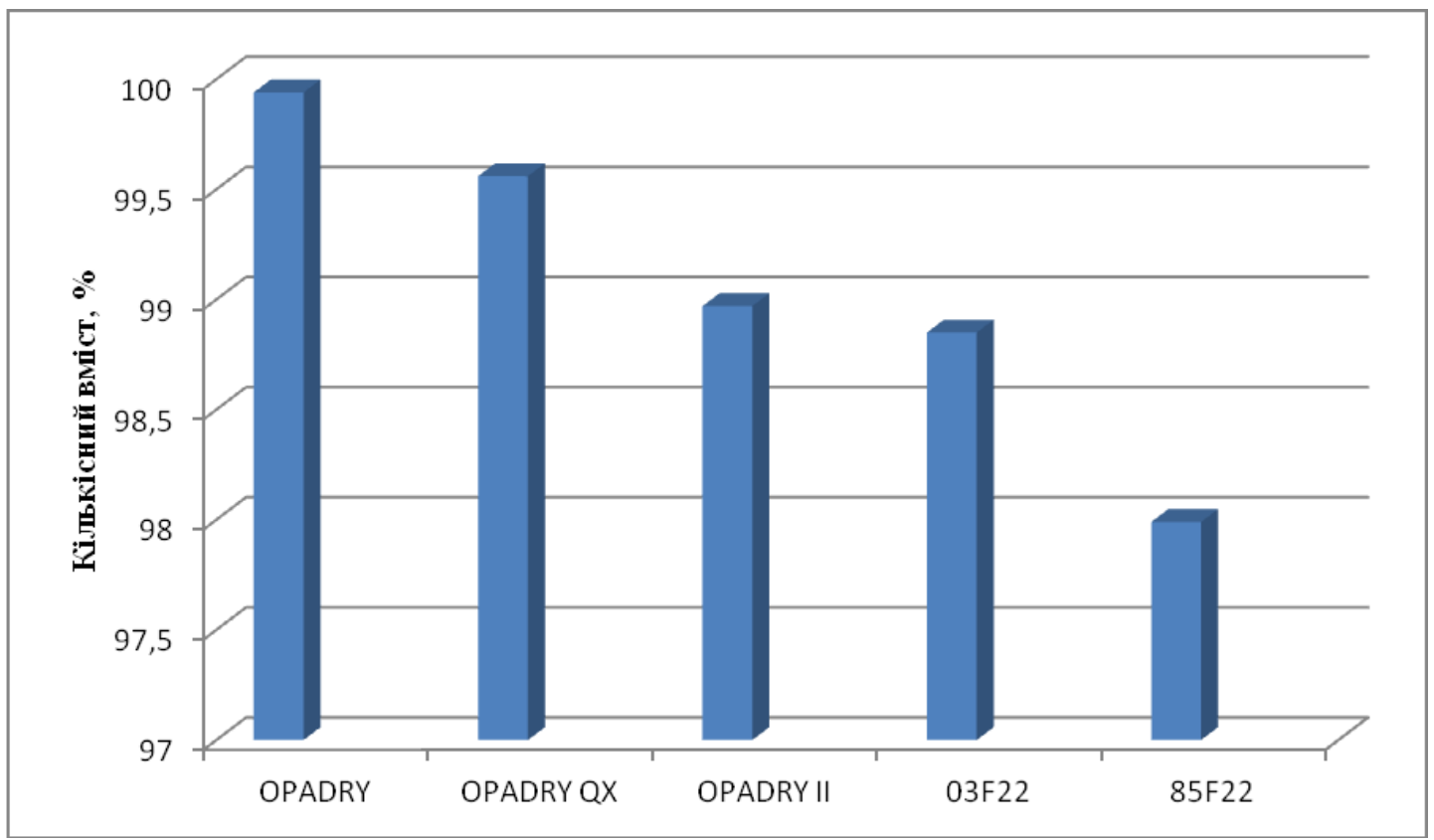

Рис. 4. Вплив природи плівкоутворюючої суспензії на кількісний вміст L-аргініну покритих таблеток L-аргініну 3 тіотриазоліном.

ми: зовнішній вигляд плівки, однорідність маси, стійкість до роздавлювання, розпадання, кількісне визначення (дані із табл. 2) переводили в безрозмірні величини за процедурою, яка описана в роботі [9]. Отримані значення наведено в таблиці 2 (грасра D i D').

Вплив різних видів плівкоутворюючого покриття на узагальнений показник таблеток
L-аргініну з тіотриазоліном показано на рисунку 5.

Аналіз експериментальних результатів за узагальненим показником показав, що найкращою плівкоутворюючою системою $є$ OPADRY $(0,95)$, яка має перевагу над OPADRY QX $(0,93), 03 F 22(0,87)$, OPADRY II $(0,79)$ i $85 F 22(0,66)$.

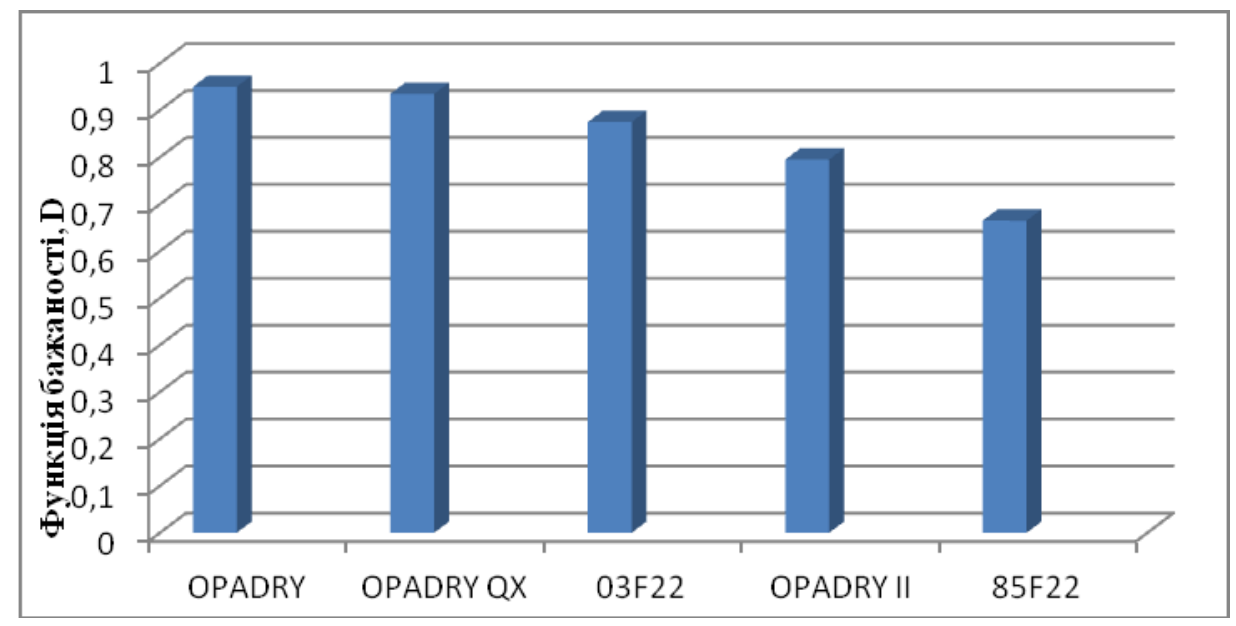

Рис. 5. Вплив різних видів плівкоутворюючого покриття на узагальнений показник таблеток L-аргініну 3 тіотриазоліном.

Висновки. Проведено дослідження 3 вибору плівкоутворюючої суспензії для покриття таблеток-ядер L-аргініну з тіотриазоліном захисною полімерною оболонкою. За сукупністю отриманих показників - зовнішнього вигляду плівки, однорідності маси покритих таблеток, стійкістю до роз- давлювання і розпаданням раціонально використовувати $15 \%$ плівкоутворюючу суспензію OPADRY.

Конфлікт інтересів: відсутній.

Conflicts of interest: author has no conflict of interest to declare.

ISSN 2312-0967. Pharmaceutical review. 2019. № 2 
Фармацевтична технологія, біофармація, гомеопатія Pharmaceutical technology, biopharmacy, homeopathy

\title{
ВЫБОР ЗАЩИТНОЙ ПОЛИМЕРНОЙ ОБОЛОЧКИ ДЛЯ ТАБЛЕТОК-ЯДЕР L-АРГИНИНА С ТИОТРИАЗОЛИНОМ
}

\author{
О. В. Хромылева \\ НПО «Фарматрон», Запорожье \\ Запорожский государственный медицинский университет \\ hromylova.olga@gmail.com
}

\begin{abstract}
Цель работы. Выбор пленкообразующей системы для покрытия таблеток-ядер L-аргинина с тиотриазолином защитной полимерной оболочкой.

Материалы и методы. В ходе работы для получения таблеток-ядер использовали субстанции тиотриазолина, L-аргинина и зарегистрированые вспомогательные вещества. Таблетки-ядра получали методом влажной грануляции в лабораторных условиях на кафедре фрармацевтической химии Запорожского государственного медицинского университета. При нанесении оболочки использовали пленкообразующие композиции торговой марки Опадрай в различных концентрациях, установку для нанесения пленкообразующего покрытия Glatt, объем барабана - 0,8 л, масса загрузки - 400 г. На таблетки-ядра наносили 3 \% пленкообразователя.

Результаты и обсуждение. В связи с тем, что исследуемые пленкообразующие покрытия при одинаковой концентрацииобеспечиваютразличнуювязкость, дляэкспериментаиспользовалирекомендованноепроизводителем Colorcon соотношение: для покрытия с ГПМЦ готовили 15 \% суспензию, а для покрытия на основе ПВС 20 и 30 \% суспензию. На таблетки-ядра наносили 3 \% пленкообразователя. Каждую серию полученных таблеток оценивали по внешнему виду, однородности массы, устойчивости таблеток к раздавливанию, распаданию. Дисперсионный анализ экспериментальных данных исследования покрытых таблеток L-аргинина с тиотриазолином показал, что среди пяти видов пленкообразующих систем лучшей является OPADRY.

Выводы. Проведены исследования по выбору пленкообразующей системы для покрытия таблеток-ядер L-аргинина с тиотриазолином защитной полимерной оболочкой. По совокупности полученных показателей - внешнему виду пленки, однородности массы покрытых таблеток, их устойчивости к раздавливанию и распаданию, рационально использовать 15 \% пленкообразующую суспензию OPADRY.
\end{abstract}

Ключевые слова: L-аргинин; инсульт; таблетки; тиотриазолин; пленочная оболочка.

\section{THE CHOICE OF PROTECTIVE POLYMER COATING FOR THE L-ARGININE WITH THIOTRIAZOLINE CORE TABLETS}

\section{O. V. Khromylova}

Zaporizhzhia State Medical University

RPA "Farmatron", Zaporizhzhia

hromylova.olga@gmail.com

The aim of the work. The choice a protective polymer film-forming system for coating of L-arginine with thiotriazoline cores tablets.

Materials and methods. In the course of work for the production of core tablets, thiotriazolin, L-arginine and registered excipients were used. The core tablets were prepared by the wet granulation method in laboratory conditions at the Pharmaceutical Chemistry Department of the ZSMU. The film-forming compositions of the Opadry brand in various concentrations, the Glatt apparatus for applying the film-forming coating were used; the volume of the drum was $0,8 \mathrm{~L}$ at $400 \mathrm{~g}$ of loading mass. $3 \%$ of the film-forming agent was applied to the core tablets.

Results and discussion. According to the fact that the film-forming coatings at the same concentration provide different viscosity, the recommended by Colorcon manufacturer were used for the experiment: $15 \%$ suspension for coating with HPMC, 20\% and 30\% suspension for PVD coating. Each series of obtained tablets was evaluated in: appearance, uniformity of mass, resistance to crushing, disintegration. The dispersion analysis of the experimental data of the coated L-arginine with thiotriazolin tablets showed, that OPADRY is the best of the five types of film-forming systems.

Conclusion: Conducted research on the choice of film-forming system for coating of core L-arginine with thiotriazoline tablets by protective polymeric film. According to the obtained indicators - the appearance of the film, the uniformity of coated tablets mass, their resistance to crushing and the disintegration, it is rational to use the $15 \%$ film-forming OPADRY suspension.

Key words: L-arginin; stroke; tablets; thiotriazoline; film coating.

ISSN 2312-0967. Фармацевтичний часопис. 2019. № 2 
Фармацевтична технологія, біофармація, гомеопатія Pharmaceutical technology, biopharmacy, homeopathy

\section{Список літератури}

1. Метаболитотропные препараты / И. А. Мазур, И. С. Чекман, И. Ф. Беленичев. - Запорожье, 2007. - 309 с.

2. Тіотриазолін: фрармакологічні аспекти та клінічне застосування / І. А. Мазур, Н. А. Волошин, І. С. Чекман [та ін.] // Новини медицини та фрармації. - 2005. $-160 \mathrm{c}$.

3. Разработка лекарственных средств на основе фриксированных комбинаций с антиоксидантами - перспективное направление современной фрармакологии / И. А. Мазур, И. С. Чекман, И. Ф. Беленичев [и др.] // Фармакологія та лікарська токсикологія. - 2011. - № 5. - С. 199-200.

4. Methabolithotropic aspects of cardioprotective action of new combined medicine based on L-Arginine and Thiotriazolin at modeling of myocardial infarction/ L. Kucherenko, I. Belenichev, I. Mazur, O. Khromylova // Asian J. Pharm. Clin. Res. - 2017. - No. 10 (10). - P. 158-161. DOI: 10.22159/ajpcr.2017.v10i10.19895

5. Патент навинахід 110597Україна, МПК(2015.01)А61K 31/198 (2006.01), А61К 9/00. Комбінований лікарський засіб гепатопротекторної, кардіопротекторної, плацентопротективної, токолітичної і NO-міметичної дії / Мазур І. А., Кучеренко Л. І., Бєленічев І. Ф., Хромильова О. В., Сюсюка В. Г.; патентовласник ТОВ
«Науково-виробниче об'єднання «Фарматрон». № a 201506388 ; заявл. 30.06.2015 ; опубл. 12.01.16, Бюл. № 1.

6. Хромильова О.В. Выбор вспомогательных веществ для получения таблеток L-аргинина c тиотриазолином методом влажной грануляции. Сообщение 1 / О. В. Хромильова // Рецепт. - 2018. № 4(21). - C. 516-524.

7. Хромильова О. В. Вивчення впливу допоміжних речовин на фрармако-технологічні характеристики таблеток L-аргініну 3 тіотриазоліном / O. B. Хромильова // Фармацевтичний часопис. - 2018. № 4 (48). - C. 35-41. DOI https://doi.org/10.11603/23120967.2018 .4 .9704

8. Державна Фармакопея України: в 3 т. / Державне підприємство «Український науковий срармакопейний центр якості лікарських засобів». - 2-е вид. - Харків : Державне підприємство «Український науковий фрармакопейний центр якості лікарських засобів», 2015. - T. 1. - 1128 c.

9. Математичне планування експерименту при проведенні наукових досліджень в фрармації / [Т. А. Грошовий, В. П. Марценюк, Л. І. Кучеренко та ін.]. - Тернопіль : Укрмедкнига, 2008. - 367 с.

\section{References}

1. Mazur IA, Chekman IS, Belenichev IF. Metabolithotropic drugs. [Метаболитотропные препараты] Zaporozhye; 2007. Russian.

2. Mazur IA, Voloshyn NA, Chekman IS. [Thiotriazoline: pharmacological aspects and clinical usage]. Novyny medytsyny i farmatsii. 2005; 160. Ukrainian.

3. Mazur IA, Chekman IS, Belenichev IF, Kucherenko LI. [The development of medicines based on fixed combinations with antioxidants is a promising area of modern pharmacology]. Farmakol ta likar toksykol. 2011;5: 19900. Russian.

4. Kucherenko L, Belenichev I, Mazur I, Khromylova O. Methabolithotropic aspects of cardioprotective action of new combined medicine based on L-Arginine and Thiotriazolin at modeling of myocardial infarction. Asian J Pharm Clin Res 2017;10 (10): 158-61.

5. Mazur IA, Kucherenko LA, Belenichev IA, Khromylova OV, Siusiuka VH. inventors; RPA "Farmatron", assignee. Комбінований лікарський засіб гепатопротекторної, кардіопротекторної, плацентопротективної, токолітичної і NO-міметичної

діï [Combination Drug with Hepatoprotective, Cardioprotective, Placentoprotective, Tocolytic and NO-Mimetic Action]. UA 110597. 2016 Jan 01. Ukrainian.

6. Khromylova OV. [Selection of excipients for L-arginine tablets with thiotriazoline by wet granulation (Report 1)]. Retsept. 2018;4(21): 516-24. Russian.

7. Khromylova OV. [Selection of excipients for L-arginine tablets with thiotriazoline by wet granulation]. Farmatsevt chasop. 2018;4(48): 35-41. DOI https://doi. org/10.11603/2312-0967.2018.4.9704

8. State Pharmacopoeia of Ukraine: in 3 vol. [Державна Фармакопея України: в 3 т.] State Enterprise Ukrainian Scientific Pharmacopoeial Center of Medicines Quality. 2nd edn. Kharkiv: State Enterprise Ukrainian Scientific Pharmacopoeial Center of Medicines Quality, 2015. Ukrainian.

9. Hroshovyi TA, Martseniuk VP, Kucherenko LI, Vronska LV, Hurieieva SM. Matematychne planuvannia eksperymentu $v$ farmatsii [Mathematical planning of experiment in pharmacy]. Ternopil: Ternopil State Medical University; 2008. Ukrainian.

\section{Відомості про автора:}

Хромильова О. В. - канд. фрармац. н., доц., каф. фрармацевтичної хімії, Запорізький державний медичний університет, м. Запоріжжя, Україна. E-mail:hromylova.olga@gmail.com, ORCID 0000-0002-5274-9676

\section{Information about author:}

Khromylova O. V. - PhD (Pharmacy), Associate Professor, the Pharmaceutical Chemistry Department, Zaporizhzhia State Medical University, Zaporizhzhia, Ukraine. E-mail:hromylova.olga@gmail.com, ORCID 0000-0002-5274-9676

ISSN 2312-0967. Pharmaceutical review. 2019. № 2 